\title{
A Review Paper on "Utilization of Fly Ash, Rice Husk Ash and Plastic Waste in Paver Blocks"
}

\author{
Mr. Satish Deoraoji Kene ${ }^{1, a} *$ Dr. Arun Patel ${ }^{2, b}$ \\ ${ }^{1}$ Ph.D Scholar, RKDF University, Gandhi Nagar Campus, Bhopal (MP), India \\ ${ }^{2}$ Professors, RKDF University, Gandhi Nagar Campus, Bhopal (MP), India
}

\begin{abstract}
The main purpose of this research paper is that, prevention from environmental pollution of agricultural and industrial waste. This can be recycle into making the paver block with cement concrete. Now a days concrete plays an important role in every construction industries practices. Paver block is an attractive engineering and inexpensive alternative to both flexible and rigid pavement in various countries together with India. Interlocking concrete pavements are special dry mix precast piece of concrete commonly used in exterior landscaping pavement applications. For better look, easy laying and finish paver block are supreme material. The strength, durability and aesthetically pleasing surfaces have made paving blocks attractive for many commercial, municipal and industrial applications such as parking areas, pedestrian walks, traffic intersections, container yards and roads. This paper is survey of the use of waste plastic, Fly ash and rice husk ash in concrete paver blocks is aimed at reducing cement content and leading to better frugality and durability. It will also help in safety of the environment effects and contribute towards the solution for safe disposal of wastage plastic, Fly ash and Rice husk ash. Waste material used as supplementary materials of cement and aggregate in the paver block like, Fly ash, Rice husk ash and plastic.
\end{abstract}

Keywords: Paver block, Fly ash, ricehuskash, plastic, Quality control and impact on environment.

\section{INTRODUCTION}

Concrete paver blocks are made with concrete basically consisting of cement, fine aggregates, coarse aggregates $(10 \mathrm{~mm}$ and below), water, etc. Overall performance of concrete paver blocks used is mainly governed by properties of materials, water cement ratio, mixing process and curing process. To suit the imagination of landscape architectures and natures, pavers are having various shapes, sizes and colours. They are placed in variety of pattern. Natural resources are depleting worldwide, at the same time the generated wastes from the industry, agriculture and residential area are increasing significantly. The sustainable development for construction involves the use of Non-conventional and innovative materials. The recycling of waste materials just like plastic, fly ash and rice husk ash in order to compensate the lack of natural resources and to find alternative ways conserving the environment.

The use of waste plastic, Fly ash and ricehuskash in concrete paver blocks is aimed at reducing cement content, aggregate and leading to better frugality and durability. It will also help in safeguarding the environment effects and contribute towards the solution for safe disposal of wastage plastic, Fly ash and Rice husk ash.

Waste material used as supplementary materials of cement in the paver block like plastic, Fly ash and Rice husk ash.

1. Rice husk ash: - Due to $98 \%$ silica content, which increases strength, hardness, strength and durability.

2. Fly ash:- Fly ash is with $\mathrm{Ca}, \mathrm{Si}$ and $\mathrm{Al} 2 \mathrm{o} 3$ etc, which provide help in setting and hardening and acts as a workability agent.

3.Plastic:- Crushed, gravelled any type of plastic can give reinforcement to cement block, which provide toughness, strength load bearing capacity lower down the weight of the block and save the quantity of aggregate etc.

In manufacturing of cement paver block resources are required as raw materials are available but in limited quantity. On the other hand imbalance of ecology and habitat occurs during the complete manufacturing processes to manufacture good quality paver block raw materials with necessary properties are required. It is possible to replace upto $30 \%$ raw materials by other materials which possess the properties necessary for good quality paver block. Rice husk ash is with $98 \%$ silica content which can be used and provides hardness, strength and durability. Rice husk ash is a waste product of industry and available easily. Fly ash is a waste product remains after burning of coal in thermal power plant which can be used as a raw material for paver block material. Fly ash is always with some percentage $\mathrm{Ca}$ and $\mathrm{Si}$ etc. Fly ash works as a workability agent during manufacturing of paver block. Third very important supplementary raw material is plastic, as we know the plastic is very big environmental problem. It can be remove out from waste and use for manufacturing of paver block or for road construction. Plastic provide reinforcement which increases tensile strength and load bearing capacity. All above three supplementary materials imparts good and necessary properties in paver block. It also helps in saving the impact on environment due to use of the resources of mother earth.

\section{LITERATURE SURVEY}

Sarang Shashikant Pawar and Shubhankar Anant Bujone ${ }^{[1]}$ (2017), thoroughly explains all the aspects of "Use of Fly ash and Plastic in Paver Block". Paver blocks are constructed by using waste like fly ash, plastic sag strip and wire plastic. In this research work the paver block made with the help of some percentage of plastic and 
flyash by weight of cement and aggregate added in concrete help to reduce plastic bag and also improve the properties of the paver block. The plastic and fly ash use in paver block will reduce the cost.

\section{B. Shanmugavalli, K.Gowtham, P. Jeba Nalwin2 and B.} Eswara Moorthy ${ }^{[2]}$ (2017) the research paper is about "Reuse of Plastic Waste in Paver Blocks". They give concepts about disposal of waste materials including waste plastic bags has become a thoughtful problem. Here the strength properties of pavement blocks including of waste plastics and the design considerations for pavement block incorporating waste plastic bags is presented. It will be a bonus to modern society and environment. The main aim is to use the plastic nature in construction fields with limited additions and the replacement of cement with plastic waste in paver block will reduce the cost of paver block when compared to that of convention concrete paver blocks. It will be absolutely a cost economical and can be applied in different practices.

Mohan D.M.S, Vignesh.J, Iyyappan.P and C.Suresh ${ }^{[3]}$ (2018) conducted a study on "Utilization of plastic bags in pavement blocks". He introduces the concept of addition of waste plastic bags with cement concrete to improve the properties of paver block. In this research work he conclude that if we are using $20 \%$ plastic by the weight of aggregate which does not affect the properties of paver block as well as the compressive strength of this block is equal to conventional block. He also conclude that the weight of plastic paver block is reduces up to $15 \%$ of conventional block and reduces the cost of construction and also helps to avoid disposal problem of plastic. Lastly he strongly conclude that the use of plastic in paver block is the best option for the disposal of plastic and ultimately reduces plastic pollution in the environment. Hence the use of plastic in paver block constituent is helpful in reducing plastic waste in a useful way.

\section{Koli Nishikant, Aiwale Nachiket, Inamdar Avadhut and} Abhishek Sangar ${ }^{[4]}$ (2016) proposes a "Manufacturing of concrete paving block by using waste glass material". This technology has been introduced in in construction for specific requirement namely footpaths, parking areas etc. In this research work he added different proportions of waste glass fine aggregate and flyash, In this research work he conclude that the use of waste glass as fine aggregate decreases the unit weight of concrete, workability of concrete mix increases with the increase in flyash and waste glass content. Also he conclude that bending strength decreases with the increase in waste glass content as well as cost of the paver block reduces. For all above conclusion it is conclude that the best ratio of fine crushed glass which leads to higher strength of concrete in order to produce concrete blocks, and the effect of waste glass replacement on the expansion caused by Alkali-silica reaction (ASR).

Dinesh.S, Dinesh.A and Kirubakaran.K ${ }^{[5]}$ (2016) presented an "Utilisation of waste plastic in manufacturing of bricks and paver blocks". In this paper he said that the large amount of plastic is being brought into the tourist trekking areas are discarded or burned which leads to the pollution of environment and air. These waste plastics are to be effectively utilised. High-density polyethylene (HDPE) and polyethylene (PE) bags are cleaned and added with sand and aggregate at various percentages to obtain high strength bricks that possess thermal and sound insulation properties to control pollution and to reduce the overall cost of construction; this is one of the greatest ways to avoid the gathering of plastic waste which is an ondegradable pollutant.

A.Panimayam, P.Chinnadurai, Anuradha and K.Pradeesh, A.Umar Jaffer [6] (2017) he studied on "Utilisation of Waste Plastics as a Replacement of Coarse Aggregate in Paver Blocks". This Paper suggests reuse of plastics as partial replacement of coarse aggregate in M20 concrete. Usually M20 concrete is used for most constructional works. Waste Plastics were progressively rises in $0 \%, 2 \%, 4 \%, 6 \%, 8 \%$ and $10 \%$ to replace the same quantity of Aggregate. Tests were conducted on coarse aggregates, fine aggregates, cement and waste plastics to determine their physical properties. Paver Blocks of I section of casted and tested for 7, 14 and 28 days strength and the result shows that the compressive strength of M20 concrete with waste plastics is $4 \%$ for Paver Blocks.

Mohammad Jalaluddin [7] (2017) researched on "Use of Plastic Waste in Civil Constructions and Innovative Decorative Material (Eco- Friendly)" presented a alteration to the use of plastic in civil construction, the mechanisms used include everything from plastic screws and hangers to bigger plastic parts that are used in decoration, electric wiring, flooring, wall covering and waterproofing. Plastic use in road construction that have shown same confidence in terms of using plastic waste in road construction, i.e. plastic roads and paver block. He said that Plastic will increase the melting point of the bitumen. Rain water will not seep through because of the plastic in the tar. So, this technology will result in lesser road repairs.

A.I. Essawy a, A.M.M. Saleh b, Magdy T. Zaky c, Reem K. Farag b, A.A. Ragab b ${ }^{[8] ~(2013)}$ researched on "Environmentally friendly road construction" this Paper proposes a reuse of waste polymers is considered an goodlooking solution for environmental white pollution and reducing of the costs of road pavement and maintenance. The environmentally friendly hot mix asphalt (HMA) for paving can be prepared using some industrial wastes as polypropylene and polyester fibres.

Ghassan Abood Habeeb*; Hilmi Bin Mahmud ${ }^{[9]}$ (2010) conducted a study on "Properties of rice husk ash and its use as cement replacement material". This paper investigates the properties of rice husk ash (RHA) produced by using a ferro-cement furnace. The effect of grinding on the particle size and the surface area was first investigated, then the XRD analysis was conducted to verify the presence of amorphous silica in the ash. Furthermore, the effect of RHA average particle size and percentage on concrete workability, fresh density, superplasticizer (SP) content and the compressive strength 
were also investigated. Although grinding RHA would reduce its average particle size (APS), it was not the main factor controlling the surface area and it is thus resulted from RHA's multilayered, angular and microporous surface. Incorporation of RHA in concrete increased water demand. RHA concrete gave excellent improvement in strength for $10 \%$ replacement $(30.8 \%$ increment compared to the control mix), and up to $20 \%$ of cement could be valuably replaced with RHA without adversely affecting the strength. Increasing RHA fineness enhanced the strength of blended concrete compared to coarser RHA and control OPC mixtures.

Nitesh kushwah and Sandeep K. Shrivastav ${ }^{[10]}$ (2019) researched on "Comparative Study on Impact of Rice Husk Ash and Fly Ash in Concrete Mix Design for Different Grades of Concrete." This study is about the addition of furnace incinerated Rice Husk Ash into concrete with fly ash. The primary objective of this research work is to investigate the mechanical properties like compressive strength and to reduce the overall cost of construction. RHA and fly ash was used to replace cement partially at different rates, fly ash is used at the rate of $0 \%, 5 \%$ and $10 \%$ and RHA at the rate of $5 \%$ and $10 \%$. The physical properties of RHA were determined by particle size analyzer. Pozzolanic reactivity of RHA is dependent on silica form. The silica form in RHA is determined by incineration process. To decide it is in crystalline form optimum cement replacement ratio of RHA and fly ash found at $5 \%+5 \%$. In this investigation firstly two lower grades concrete M-15 and M-20 were prepared and the best result was found with M--15 grade of concrete, then experiment were done with higher grades i.e. M-30 and M35 grades and there is slight increase in compressive strength in higher grades.

MOHAMED AMIN AND BASSAM ABBDELSALAM ABBDEL SALAM [11] (2019) conducted a study on "Efficiency of rice husk ash and fly ash as reactivity materials in sustainable concrete." This paper presents the recycling of rice husk ash (RHA) and fly ash (FA) from power plants as reactivity materials for producing sustainable (green) concrete. This research aims to investigate the efficiency of RHA and FA replacement ratios on fresh and hardened properties of concrete mixtures. The experimental program consisted of 21 concrete mixtures, which were divided into three groups. The cementitious material contents were 350,450 and $550 \mathrm{~kg} \mathrm{~m}-3$ for groups one, two and three, respectively. The replacement ratios from the cement content were 10, 20 and $30 \%$ respectively, for each recycle material (RHA and FA). The slump and air contents of fresh concrete were measured. The compressive strength, splitting tensile strength, flexural strength, and modulus of elasticity and bond strength of hardened concrete as mechanical properties were also analysed. The compressive strength was monitored at different ages: 3, 7, 28, 60 and $90 \mathrm{~d}$. The water permeability test of hardened concrete as physical properties was conducted. Test results showed that the RHA and FA enhanced the mechanical and physical properties compared with the control mixture. The cementitious content of $450 \mathrm{~kg} \mathrm{~m}-3$ exhibited better results than other utilized contents. In particular, the replacement ratios of 10 and $30 \%$ of RHA presented higher mechanical properties than those of FA for each group. The water permeability decreased as the cementitious content increased due to the decrease in air content for all mixtures. The water permeability loss ratios increased as the cementitious content decreased.

Satish H. Sathawanea, Vikrant S. Vairagadeb and Kavita S Kene ${ }^{[12]}$ (2013) presented a "Combine Effect of Rice Husk Ash and Fly Ash on Concrete by 30\% Cement Replacement". The work presented in this paper reports the effects on the behaviour of concrete produced from cement with combination of FA and RHA at different proportions on the mechanical properties of concrete such as compressive strength, flexural strength, and split tensile strength. Investigation reported that compressive strength increases by $30.15 \%$ in compared with targeted strength and reduces by $8.73 \%$ compared with control concrete at 28 days, flexural strength increases by $4.57 \%$ compared with control concrete at 28 days, split tensile strength decreases by $9.58 \%$ compared with control concrete at 28 days, were obtained at combination of $22.5 \%$ FA and $7.5 \%$ RHA. Partial replacement of FA and

RHA reduces the environmental effects, produces economical and eco-friendly concrete.

\section{CONCLUSION}

This survey paper gives the detail survey of the work carried out in paver block made with the help of plastic, fly ash and rice husk ash. Paver block made by three composite materials, has a high compressive strength. The main constituents of paver block are cementing concrete. The above literature survey shows that the used of plastic $\&$ fly-ash in different proportions. The desired strength is achieved but at the expense of more cements consumption which also increases the cost of product. In the view of above literature we found that the consumption of cement may be reduce by addition of rice husk ash. A renewable zero cost material for the construction of cost effective paver blocks.

It is found after analysis that there is need of some advanced paver block made with the help of all three basic waste materials generated in agricultural and industrial area that is plastic, flyash and ricehuskash. The proposed paver block is also expected to be cost efficient (effective) as compared to cement concrete paver block strength as we are going to use the zero cost waste plastic, fly ash and rice husk ash. In the proposed paver block as we are using light weight waste material like plastic and rice husk ash, replacing heavier cement material producing light weight, easy transportable paver blocks. Hence we are proposing a process which will reduce the hazardous materials in the environment like plastic, fly ash and rice husk ash etc. therefore by implementing paver block; we are capable to offer a green technology, sustainable construction and environment friendly product to the society. 
All above three supplementary materials imparts good and necessary properties in paver block and also helps in saving the impact on environment due to use of the resources of mother earth.

\section{REFERENCES}

[1] Sarang Shashikant Pawar and Shubhankar Anant Bujone (2017). "Use of Fly ash and Plastic in Paver Block". International research journal of Engineering and Technology (IRJET) Volume: 04 Issue: 11|Nov - 2017.

[2] Shanmugavalli, K.Gowtham, P. Jeba Nalwin2 and B. Eswara Moorthy (2017). "Reuse of Plastic Waste in Paver Blocks". International research journal of Engineering and Technology (IRJET) Volume: 06 Issue: 02|Feb - 2017.

[3] Mohan D.M.S, Vignesh.J, Iyyappan.P and C.Suresh (2018). "Utilization of plastic bags in pavement blocks". International journal of pure and applied mathematics. Volume: 119 Issue: $15 \mid \mathrm{Feb}-2018$.

[4] Koli Nishikant, Aiwale Nachiket, Inamdar Avadhut and Abhishek Sangar (2016). "Manufacturing of concrete paving block by using waste glass material" International journal of Scientific and Research Publications, Volume: 06 Issue: 06|June - 2016.

[5] Dinesh.S, Dinesh.A and Kirubakaran.K (2016). "Utilisation of waste plastic in manufacturing of bricks and paver blocks" International journal of applied engineering research, ISSN 0973 - 4562 Vol.11 No. 3 (2016)

[6] A.Panimayam, P.Chinnadurai, Anuradha and K.Pradeesh, A.Umar Jaffer (2017). "Utilisation of Waste Plastics as a Replacement of Coarse Aggregate in Paver Blocks" International journal of ChemTech Research CODEN (USA): IJCRGG, ISSN: 0974-4290 Vol.10 No.8, pp211-218 (2017).

[7] Mohammad Jalaluddin (2017). "Use of Plastic Waste in Civil Constructions and Innovative Decorative Material (EcoFriendly)" MOJ Civil Engineering, Review Article Volume 3 Issue $5-2017$.

[8] A.I. Essawy a, A.M.M. Saleh b, Magdy T. Zaky c, Reem K. Farag b, A.A. Ragab b (2013). "Environmentally friendly road construction" Egyptian journal of Petroleum (2013) 22, 189-198.

[9] Ghassan Abood Habeeb*; Hilmi Bin Mahmud (2010). "Properties of rice husk ash and its use as cement replacement material". Materials Research Print version ISSN 1516-1439, Mat. Res. vol.13 no.2 São Carlos Apr. /June 2010.

[10] Nitesh kushwah and Sandeep K. Shrivastav (2019). "Comparative Study on Impact of Rice Husk Ash and Fly Ash in Concrete Mix Design for Different Grades of Concrete." (IJATER) Volume 9, Issue 1, January 20194 Pages Posted: 12 Jul 2019.

[11] Mohamed Amin and Bassam Abbdelsalam Abbdelsalam (2019). "Efficiency of rice husk ash and fly ash as reactivity materials in sustainable concrete." Sustainable Environment Research volume 29, Article number: 30 (2019).

[12] Satish H. Sathawanea, Vikrant S. Vairagadeb and Kavita S Kene (2013). "Combine Effect of Rice Husk Ash and Fly Ash on Concrete by $30 \%$ Cement Replacement" SciVerse ScienceDirect ,Proceia Engineering 51 (2013) 35-44.. 